\title{
GÊNERO E POLÍTICAS PARA MULHERES NO BRASIL: Reflexões em torno de uma experiência doída ${ }^{1}$
}

\author{
Cecília M. B. Sardenberg ${ }^{(*)}$
}

\section{Resumo}

Nos meus quase quarenta anos como antropóloga feminista atuando nos movimentos de mulheres, na academia, como consultora em projetos internacionais e na formulação, implementação e monitoramento de políticas públicas para mulheres no Brasil, venho acumulando experiências reveladoras de que, nem sempre, as tentativas de tradução de um desses campos de ação feminista para o(s) outro(s) resultam em "uniões felizes" entre teoria e práxis. Nesse campo de disputas entre perspectivas distintas e distintos atores sociais e institucionais, a teoria feminista é traduzida e ressignificada, perdendo sua força original, e os objetivos maiores muitas vezes dão lugar à pequenez. Volto-me aqui para algumas dessas experiências mais tensas e conflituosas - experiências "doídas" - de consultorias de gênero em projetos de desenvolvimento rural na Bahia, procurando refletir sobre os impasses éticos, práticos, políticos e teórico-metodológicos, dentre outros, confrontados na operacionalização da teoria feminista para aplicação prática em políticas e projetos, com ênfase na conceituação de gênero e empoderamento de mulheres.

Palavras-chave: Gênero e Empoderamento de Mulheres. Gênero e Desenvolvimento.Teoria e Práxis Feminista no Campo. Bahia.

\begin{abstract}
In my nearly forty years as a feminist anthropologist active in women's movements, in academics, as consultant to international projects, and in the formulation, implementation, and monitoring of public policies for women in Brazil, I have accumulated several experiences which revealed that attempts to translate one of these feminist action fields into another have not always resulted in "happy unions" between theory and praxis. Feminist theory is translated and re-signified amidst disputes between distinct perspectives and distinct social and institutional actors, losing its original force, while major objectives often give way to mediocrity. In this paper, I turn to some of the more tense and conflicting experiences - to painful experiences - I have faced as gender consultant in rural development projects in Bahia, reflecting upon the ethical, practical, political, and theoretical-methodological dilemmas confronted in operationalizing feminist theory into practical application in policies and projects, with a focus on conceptualizations of gender and women's empowerment.
\end{abstract}

Keywords: Gender and Women's Empowerment. Gender and Development. Feminist Theory and Praxis in Rural Contexts. Bahia.

\section{Introdução}

\footnotetext{
${ }^{1}$ Este trabalho foi elaborado, originalmente, para apresentação ao GT 85 Estudos de Gênero: Da Pesquisa à Politica, XII Conlab - Congresso Luso-Afro-Brasileiro, Lisboa, 1 a 5 de fevereiro de 2015. Algumas das ideias aqui desenvolvidas foram discutidas inicialmente em um artigo escrito em colaboração com Elizete Passos e Ana Alice Costa, publicado em Gender and Development (SARDENBERG; PASSOS; COSTA, 1998) e em minha apresentação no encontro sobre mulheres rurais realizado em junho de 2000, na Humbolt-University, em Berlim, Alemanha, publicada, posteriormente, nos anais do evento (SARDENBERG, 2000). Veja-se também Sardenberg (2010; 2014).

${ }^{(*)}$ Doutorado em Antropologia Social pela Boston University - Estados Unidos. Professora Assistente IV da Universidade Federal da Bahia - NEIM/UFBA. E-mail: cecisard@ufba.br.
} 
Dentre as importantes conquistas dos movimentos feministas no plano internacional, destacam-se as conferências internacionais de mulheres promovidas pela Organização das Nações Unidas-ONU, bem como os planos, convenções e plataformas de ação daí resultantes, que vêm contribuindo para a incorporação do enfoque de equidade de gênero em políticas públicas e em projetos e/ou programas de desenvolvimento. Para tanto, dentre outras profissionais e ativistas, muitas de nós, feministas acadêmicas, temos sido chamadas a colaborar com esses esforços, no sentido de promover uma maior participação de mulheres em todos os níveis e contribuir para o seu empoderamento. No entanto, desenvolver políticas, programas e projetos que trabalhem, de fato, com a perspectiva da equidade de gênero e do empoderamento de mulheres não tem sido uma tarefa fácil (SARDENBERG, 2010: 39). Inúmeros obstáculos surgem nesse processo, não raro em virtude das próprias ideologias que subjazem às políticas de desenvolvimento, somadas à resistência, por parte dos planejadores e executores dos projetos, em incorporar essa nova perspectiva. Em muitos casos, essa perspectiva tem vindo de "cima para baixo" como exigência de agências internacionais, ou mesmo sem considerações maiores quanto às características do contexto local e com pouca atenção à necessária sensibilização e capacitação para as equipes e comunidades envolvidas. Ademais, tensões e conflitos gerados pelo jogo de poder nas instituições e agências implicadas criam toda sorte de entraves na concretização das políticas e programas em questão, de sorte que a perspectiva de gênero por fim incorporada pode se distanciar bastante da concepção feminista dos planos iniciais (SARDENBERG, 2014; PISCITELLI, 2005).

Sonia Alvarez (2009:743) bem ressalta que "[...] discursos e práticas feministas viajam por uma variedade de lugares e direções e acabam se tornando paradigmas interpretativos para a leitura/escrita de questões de classe, gênero, sexualidade, migração, saúde, cidadania, política e circulação de identidades e textos." Entretanto, segue a autora, “[...] essas viagens estão mergulhadas em questões mais amplas de globalização e envolvem trocas entre várias localidades [...]." Isso se torna ainda mais complexo no campo de "gênero e desenvolvimento", vez que aí participam, não apenas ativistas em diferentes campos de ação, mas também representantes de instituições governamentais e não-governamentais, bem como de agências de financiamento internacionais e, é lógico, dos diferentes segmentos que constituem a população alvo, constituindo um amplo leque de agentes que “[...]se apropriam e ressignificam os conceitos que surgiram no seio do pensamento feminista" (PISCITELLI, 2005, p.144). Conforme observei em trabalho anterior sobre o conceito de gênero (SARDENBERG, 2014, p.20), se por um lado as teorias feministas viajantes e suas traduções tem o poder de intervir nos contextos para os quais são importados, por outro, “[...] são quase sempre vítimas de desvios semânticos, se não de total ressignificação", encontrando, nessas diferentes migrações, "[...] coações epistemológicas, institucionais e políticas, fazendo com que passem por terrenos 
imperfeitos, peguem desvios súbitos e encontrem armadilhas ocasionais" (COSTA, 2000, p. $45)$.

Nesses meus mais de quarenta anos atuando como antropóloga feminista, militando em diferentes campos de ação - nos movimentos de mulheres, na academia, como consultora em projetos internacionais e na formulação, implementação e monitoramento de políticas públicas para mulheres no Brasil -, venho acumulando experiências reveladoras de que são raras as instâncias em que tentativas de tradução de uma dessas faces da militância para a(s) outra(s) resultam em "uniões felizes" entre teoria e práxis. Nesse campo de disputas entre perspectivas distintas e distintos atores sociais e institucionais, muitas vezes os objetivos maiores se perdem dando lugar à pequenez, limitando as possibilidades de alcance das metas traçadas.

Confesso que algumas dessas experiências de "tradução" por mim vivenciadas foram até mesmo bastante "doídas", tal qual se deu no Projeto Gavião, um projeto de desenvolvimento rural implementado por um órgão do Estado da Bahia com financiamento do Fundo Internacional de Desenvolvimento Agrário - FIDA/ONU. Integrei a equipe do Núcleo de Estudos Interdisciplinares sobre a Mulher-NEIM, da Universidade Federal da Bahia/UFBA, encarregada de elaborar um trabalho de assessoria ao Projeto. Mas as tensões e conflitos que marcaram o trabalho, desde o início, resultaram no nosso afastamento, deixando que outros levassem a termo o programa que formulamos.

Neste artigo, beneficiando-me do distanciamento que o passar do tempo (quase duas décadas) oferece, pretendo relatar os meandros dessa experiência, buscando refletir sobre o complicado processo de "traduções" das teorias feministas. Inicio com uma breve discussão sobre os desdobramentos que levaram à incorporação da perspectiva de gênero em projetos e programas de desenvolvimento e sobre as limitações impostas pelas ideologias subjacentes às noções sobre desenvolvimento e empoderamento de mulheres postas em jogo. A seguir, delineio o projeto e o contexto regional e de gênero em que foi implementado, discutindo os caminhos percorridos para operacionalizar nossas teorias e as limitações advindas das "ressignificações" impostas.

\section{Gênero, Desenvolvimento e Empoderamento de Mulheres}

Até fins dos anos 1950 perdurou a ideia de que, gradualmente, o desenvolvimento econômico chegaria à sociedade como um todo, deslanchando um processo de 'modernização'. Suponha-se que o desenvolvimento beneficiaria a todos de maneira igual, ou seja, "que aquilo que beneficiasse um setor da sociedade (homens), automaticamente afetaria outro setor (as mulheres)" (WILLIAMS, 1999, p.94). Em consequência, as políticas para mulheres na perspectiva do desenvolvimento permaneceram no contexto da questão dos direitos humanos e 
restritas à Comissão do Status da Mulher $(\mathrm{CSW})$ e outros órgãos da ONU, responsáveis por questões sociais e humanitárias (KABEER, 1994).

A partir da emergência dos movimentos feministas nos anos 1960 e crescente presença de mulheres inseridas nas organizações internacionais pressionando por mudanças, questões referentes aos direitos das mulheres passaram finalmente a integrar discursos e práticas sobre desenvolvimento. Em 1973, foi aprovada a Emenda Percy (Percy Amendment), que demandava “[...] estudos de impacto social, sensíveis ao gênero, em todos os projetos de desenvolvimento, com a perspectiva de integrar as mulheres nas economias nacionais de seus países" (CONNELLY et alli, 2000, p.56, tradução nossa). Essa perspectiva também conquistou o apoio de técnicos/as e consultoras/es nas agências e organizações vinculadas à ONU e, em tempo, de representantes de delegações de diferentes países, levando à decretação de 1975 como Ano Internacional da Mulher e da realização, em junho daquele mesmo ano, da I Conferência Mundial da Mulher a ter lugar na Cidade do México.

Nessa I Conferência, foi aprovado o Plano de Ação Mundial para as Mulheres e deslanchada a Década da Mulher e Desenvolvimento para implementá-lo. Mas esse plano de ação vinha sublinhado por um pensamento feminista dito 'liberal', baseado, por sua vez, nos preceitos da economia neoclássica em combinação com as "teorias da modernização" (ou de "ocidentalização"). Nessa perspectiva, desenvolvimento era entendido como um processo "[...] linear pelo qual povos atrasados, presos à tradição, se livram de seus impedimentos históricos e abraçam as instituições, tecnologias e valores modernos (isto é, Ocidentais)" (CONNELLY et al, 2000, p.55, tradução nossa). Daí porque, em grande parte, os esforços para o desenvolvimento se voltavam para estratégias que, supostamente, pudessem fazer as economias ditas pobres, "tradicionais", finalmente "deslancharem" e fazerem a transição para a "modernidade" de uma forma mais rápida, valendo-se para tanto do apoio financeiro e técnico das agências de cooperação internacional.

O Plano de Ação para Mulheres se encaixava perfeitamente nessa perspectiva; seu propósito maior era promover a "integração das mulheres ao desenvolvimento", uma abordagem que ficou conhecida por "WID" (Women in Development) - em português, como MED Mulheres em Desenvolvimento. Orientando-se pela perspectiva feminista liberal, não questionava as abordagens tradicionais sobre desenvolvimento em voga, procurando apenas estender as 'oportunidades' do processo de desenvolvimento para as mulheres (KABEER, 1994; RAZAVI; MILLER, 1995). Isso se daria por meio de estratégias de superação da discriminação contra as mulheres, vista como causa principal das barreiras sociais e culturais para o avanço feminino, promovendo-se, para tanto, reformas legais e provisões para se garantir acesso igual para mulheres na educação e programas de treinamento (WILSON, 2004). Contudo, a abordagem MED não considerava as estruturas de poder patriarcais subjacentes às 
desigualdades entre homens e mulheres, tampouco as estruturas de dominação de classe, raça, etnicidade e outros determinantes das desigualdades entre mulheres (SEN; GROWN, 1988).

Por certo, a abordagem MED contribuiu para a expansão do campo de estudos sobre mulheres e desenvolvimento, tornando evidente a necessidade de melhorias na coleta de estatísticas sobre mulheres e de um maior conhecimento acerca da situação das mulheres em diferentes sociedades (KABEER, 1994). Passou-se a pensar as mulheres tanto como agentes quanto beneficiárias nos diferentes setores e níveis do processo de desenvolvimento, o que deu margem à constatação de que, de um modo geral, as políticas e programas de desenvolvimento vinham até então reforçando os limites entre as esferas doméstica e extra doméstica, favorecendo a domesticidade feminina, às custas do seu papel produtivo e em atividades comunitárias (KABEER, 1994; ROGERS, 1981).

Observou-se, também, que as novas tecnologias para a modernização da agricultura e a ênfase na comercialização tiveram como consequência a intensificação do trabalho do feminino - sobretudo em atividades maçantes e cansativas - sem contudo implicar em sensíveis incrementos de salários e renda familiar, principalmente no que diz respeito às mulheres. Nesse tocante, aliás, as análises sobre o trabalho feminino constataram que, na maioria dos países, havia - e continua a haver - um grande descompasso entre a imensa carga de trabalho assumida por mulheres e a sua quase total falta de controle, não apenas sobre os recursos existentes (por exemplo, elas raramente tinham a propriedade da terra utilizada na produção), mas também sobre os produtos do seu trabalho (KABEER, 1994; UNITED NATIONS, 1989).

Mas tal situação não poderia ser atribuída ao "subdesenvolvimento" ou às tradições ditas "atrasadas" do meio rural. Experiências semelhantes também eram vivenciadas por mulheres nas sociedades industrializadas, ditas modernas e desenvolvidas, como nos Estados Unidos e países da Europa. Ademais, também nesses países "desenvolvidos" a participação das mulheres na produção tendia a ser subestimada, subvalorizada ou mesmo ignorada. Isso demonstrou que o "desenvolvimento", per se, não contribuía automaticamente para o empoderamento das mulheres e erradicação das desigualdades de gênero (KABEER, 1994). Até mesmo nos países mais "desenvolvidos" as mulheres permaneciam sendo as principais responsáveis pelas atividades "reprodutivas" - as atividades domésticas e o cuidado das crianças -, o que contribuía para a desvalorização das suas atividades produtivas e comunitárias (YOUNG; WOLKOWITZ; McCULLAGH, 1984).

Tais constatações levaram à elaboração de um dos principais documentos internacionais em defesa dos direitos das mulheres: a "Convenção pela Eliminação de Todas as Formas de Discriminação Contra as Mulheres", melhor conhecida como "CEDAW" (sigla vinda do título em inglês: Convention for the Elimination of All Forms of Discrimination Against Women), adotada pela Assembleia Geral da ONU em 1979. Essa Convenção deu procedimento ao Plano de Ação de 1975, formulando uma agenda para ações de combate à discriminação contra 
mulheres no âmbito nacional. Mas, apesar da sua relevância, a CEDAW, tal qual a abordagem MED, também não lidava com as questões mais profundas, ao ignorar os pressupostos subjacentes ao modelo de desenvolvimento ao qual buscava integrar as mulheres (KABEER, 1994; RAZAVI; MILLER, 1995).

Durante a Década das Mulheres (1975-1985), independente dos esforços MED, os movimentos feministas e de mulheres foram ganhando força nos países ditos 'do Sul', se articulando em torno de uma série de questões, tendo o 'empoderamento de mulheres' como objetivo maior, ainda que não delineado explicitamente nesses termos. Formularam também críticas à abordagem MED, valendo-se para tanto dos novos desenvolvimentos de teorizações feministas do Norte. Em particular, essas críticas enfatizavam a construção social de gênero e as relações de poder, incorporando as discussões das feministas negras norte-americanas sobre a interseccionalidade de gênero, raça e classe que dava margem às desigualdades entre mulheres, destacaram os determinantes macroestruturais e, portanto, se afastaram do pensamento feminista liberal (KABEER, 1994; SEN; GROWN, 1988).

Esse pensamento feminista dito do "sul" se fez presente na III Conferência Mundial de Mulheres realizada em Nairobi, Quênia, em 1985, com a participação de mulheres de todo mundo para avaliar os avanços alcançados durante a Década da Mulher. Retomando os temas constantes do Plano de Ação formulado em 1975 - igualdade, desenvolvimento e paz, com os subtemas saúde, educação e emprego - as participantes identificaram os obstáculos enfrentados pelas mulheres e traçaram 'Estratégias para o Futuro'. Implícita nessas 'estratégias', estava a perspectiva de gênero, ressaltando-se a necessidade de se trabalhar no sentido do 'empoderamento' das mulheres no desenvolvimento. ${ }^{2}$

Essa questão se tornou foco principal das discussões na IV Conferência Internacional da Mulher, realizada pela ONU em 1995, em Beijing, China, quando se formulou um Plano de Ação e se deliberou - mas não sem muitos debates (BADEN; GOETZ, 1997) - a favor da incorporação do enfoque de gênero em todos os programas e projetos de desenvolvimento apoiados por órgãos e agências da $\mathrm{ONU}$, com o propósito de promover a maior participação e o empoderamento das mulheres. De fato, a Plataforma de Ação de Beijing, aprovada durante essa Conferência, não só incorporou essa nova perspectiva, como também vinculou a questão da equidade de gênero ao empoderamento de mulheres, nos seguintes termos: "O empoderamento da mulher e sua total participação, em base de igualdade, em todos os campos sociais, incluindo a participação no processo decisório e o acesso ao poder, são fundamentais para a realização da igualdade, do desenvolvimento e da paz" (UNITED NATIONS, 1995, parágrafo 13). ${ }^{3}$

\footnotetext{
${ }^{2}$ Veja-se: http://www.un-documents.net/nfl-intr.htm

${ }^{3}$ Veja-se: http://www.unfpa.org.br/Arquivos/declaracao beijing.pdf
} 
Note-se, em especial, que a Plataforma de Ação de Beijing se configura como o primeiro documento das conferências da mulher da ONU que, de fato, adota o conceito de "gênero", formalizando, assim, a passagem da perspectiva "Mulher em Desenvolvimento" para a de "Gênero e Desenvolvimento", ou seja, de MED para GED (RAZAVI; MILLER, 1995). A Plataforma se refere especificamente à equidade de gênero, estabelecendo que semelhanças $\mathrm{e}$ diferenças entre mulheres e homens devem ser reconhecidas e valorizadas, sendo que mulheres e homens devem gozar de status, reconhecimento e consideração iguais, e de condições iguais para realizar seu potencial e ambições, participar, contribuir e se beneficiar dos recursos e desenvolvimento social, bem como para desfrutar de liberdade, qualidade de vida e resultados iguais (UNITED NATIONS, 1995).

Por sua vez, essa perspectiva implicou uma proposta de gender mainstreaming, ou seja, de transversalização do enfoque de gênero nas políticas e planos, de sorte a favorecerem os interesses estratégicos das mulheres no sentido da transformação social. Essa perspectiva foi explicitada pelas participantes de um seminário promovido por organizações não governamentais feministas de países da Europa, no qual se afirmou que:

\begin{abstract}
Mainstreaming é uma estratégia para integrar os interesses e experiências, tanto de mulheres, quanto de homens, no desenho implementação, monitoramento e avaliação de políticas e programas em todas as esferas políticas econômicas e sociais, de sorte que mulheres e homens beneficiem igualmente. Igualdade e equidade de gênero são seus objetivos. O objetivo mais amplo é o pleno exercício e benefício de todos os direitos humanos (civis, políticos, sociais, econômicos e culturais) por todas as mulheres, homens e crianças. (BEDLINGTON, 2004, p.4).
\end{abstract}

Isso se traduz em uma estratégia que busca construir a equidade inserindo a análise de gênero, pesquisas sensíveis para a questão de gênero, a perspectiva das mulheres e os objetivos de equidade entre os sexos nas políticas, projetos e instituições "centrais" ou "principais", ou seja, mainstream, de uma dada sociedade. Note-se, porém, que estudiosas da questão ressaltam a importância do "caminho de mão dupla" (twin-track approach) na implementação da estratégia de mainstreaming, destacando que não basta apenas tranversalizar o enfoque de gênero em todas as esferas de ação. É preciso também desenvolver projetos e programas específicos para mulheres, particularmente aqueles que promovam o seu empoderamento (FERREIRA, 2003).

Por isso mesmo, embora as estratégias de transversalização de gênero envolvam procedimentos técnicos fundamentais - por exemplo, organizar rotinas, procedimentos, definir responsabilidades e capacidades para incorporar a perspectiva de gênero em uma determinada instituição - elas não se reduzem apenas a uma "abordagem tecnocrática". Ao contrário, tratase de uma instância de estratégia que exige, como elemento fundamental, a construção de uma vontade política (VERLOO, 1999).

Embora a introdução dessa perspectiva nos discursos e ações para o desenvolvimento tenha sido (e ainda seja) alvo de críticas, tanto de feministas radicais quanto de fundamentalistas 
(BADEN; GOETZ, 1997), seu impacto nas políticas e programas não deve ser subestimado. Atualmente, quase todas as agências de cooperação internacional e de desenvolvimento procuram incorporar essa perspectiva em seus projetos e programas, reconhecendo sua importância. Não por acaso, a equidade de gênero e empoderamento de mulheres foram definidos como "gols do Milênio." O que repercutiu com certa força nas políticas das agências de desenvolvimento. Por exemplo, em 2005, “[...] mais de 1,800 projetos do portfolio de empréstimos do Banco Mundial mencionavam empoderamento na sua documentação" (ALSOP et alli, 2006, p.1, minha tradução).

Todavia, apesar desses esforços, existe uma grande divergência entre as noções de gênero que subjazem essas políticas e projetos. A intenção de feministas ao introduzir a perspectiva de gênero no campo de desenvolvimento era trazer a questão das relações de poder desiguais entre homens e mulheres, chamando atenção para as estruturas patriarcais subjacentes (KABEER, 1994). Contudo, a 'massificação' do uso do conceito nos projetos e políticas tem levado a sua simplificação, perdendo-se, no processo, a perspectiva 'relacional' e a noção de poder (SARDENBERG, 2014; SIMIÃO, 2002). Daí porque há também grande divergência quanto aos fatores que contribuem para a equidade de gênero ou, inversamente, o que cria obstáculos nesse sentido.

De um modo geral, acredita-se que o empoderamento de mulheres seja um fator fundamental. Mas não existe concordância quanto ao que se entende por "empoderamento" e, portanto, de que forma se pode melhor promovê-lo. Conforme bem ressaltou Srilatha Batliwala (1994, p.1), empoderamento “[...] é um dos termos mais soltos usados no léxico do desenvolvimento, significa coisas diferentes para pessoas diferentes - e o que é mais perigoso, tudo para todas as pessoas". Algo semelhante ao que ocorre com o conceito de gênero (SARDENBERG, 2014).

A despeito dessas discordâncias nas definições, concordo com Ann Ferguson (2004) em que é possível distinguirmos duas abordagens básicas na conceituação de empoderamento de mulheres (SARDENBERG, 2008a). A primeira, que identifico como "empoderamento na perspectiva liberal", entende o empoderamento de mulheres principalmente como um instrumento para as prioridades do desenvolvimento. Consistente com os ideais neoliberais e uma perspectiva de complementaridade de gênero, sua ênfase recai no crescimento individual, dentro de um olhar atomístico, isto é, dentro da noção de uma ação racional de atores sociais em defesa de seus interesses individuais (ROMANO, 2002).

Em contraste, na outra abordagem - que aqui caracterizo como "empoderamento para a libertação" - a questão das relações de poder é o eixo central. Nessa perspectiva, o empoderamento de mulheres é entendido tanto como um processo por meio do qual as mulheres conquistam autonomia e autodeterminação, quanto como um instrumento para a erradicação das estruturas patriarcais. Ou seja, é um processo instrumental não apenas para a transformação 
social, como também como um fim em si próprio, na medida em que implica na libertação das mulheres das correntes da opressão de gênero. Tal abordagem é consistente com a organização de mulheres para ações coletivas, sem, contudo, menosprezar a relevância do empoderamento feminino em termos individuais.

Feministas ditas 'do Sul' tendem a entender "empoderamento" nessa perspectiva libertadora, afirmando que tal processo implica em provocar "[...] mudanças na distribuição do poder, tanto ao nível das relações interpessoais quanto das instituições da sociedade" (STROMQUIST, 2002, p.28, minha tradução). Essa perspectiva tem suas origens nas oficinas de conscientização e ação dos feminismos, surgidos nos Estados Unidos em meados dos anos sessenta, sedimentando a retomada do movimento, e que levantaram a bandeira do "pessoal é político', como seu princípio maior (SARDENBERG, 2008a). Mais recentemente, essas oficinas se desdobraram em 'pedagogias feministas', também inspiradas na "pedagogia do oprimido". Tal qual outras pedagogias alternativas, libertadoras, essas pedagogias procuram propiciar processos de empoderamento, tanto coletivo quanto individual, que não se adequam às propostas neoliberais da maioria dos projetos de "gênero e desenvolvimento" em curso (SARDENBERG, 2008b).

Como veremos mais adiante, no projeto em questão trabalhamos com uma perspectiva de equidade de gênero e empoderamento para a libertação, dentro de uma perspectiva relacional de gênero, enquanto as expectativas da direção do projeto se apoiavam na noção de empoderamento liberal e em uma noção mais estrita, complementar, de gênero. Conforme fomos por fim informadas, eles queriam que implementássemos "gênero" no projeto ao invés de "fazer feminismo."

\section{A Região do Rio Gavião}

Desbravar o semiárido baiano pode ser uma experiência bastante desgastante, principalmente quando se é obrigada a fazê-lo no lombo de uma caminhonete Toyota, apinhada de gente, visitando 13 municípios em menos de uma semana e, pior ainda, literalmente "comendo poeira na estrada" e dormindo em pensões e pousadas sem conforto ao longo do caminho. ${ }^{4}$ Mas tudo isso é suportável e compensado quando se acredita que nosso trabalho pode fazer uma diferença. Movidas por essa crença, minhas companheiras do NEIM, Ana Alice Costa, Elizete Passos e eu não só acatamos o convite para elaborarmos um Programa de Assessoria em Gênero - o 'PAGE', para o Projeto Gavião, como nos dispusemos a executá-lo,

\footnotetext{
${ }^{4} \mathrm{O}$ treze municípios dessa região são: Anagé, Belo Campo, Caraíbas, Condeúba (sede coordenação local), Cordeiros, Guajerú, Jacaraci, Licínio de Almeida, Maetinga, Mortugaba (sede coordenação local), Piripá, Presidente Jânio Quadros (sede coordenação local) e Tremedal (sede coordenação local e coordenação regional).
} 
passando mais de dois anos (1998-2000) viajando todos os meses pelo sertão baiano, em condições nem sempre das mais agradáveis.

Tratava-se de um projeto de grande porte desenvolvido em treze municípios localizados no centro-sul do Estado da Bahia, distribuídos em uma área de $11.718 \mathrm{Km} 2$, na região do Rio Gavião. Essa é uma área bastante inóspita, caracterizada por vegetação de caatinga, embora inclua também outras sub-regiões ecológicas, algumas com solos bem mais férteis. O problema maior, porém, é a seca que assola toda a região periodicamente, podendo se estender por mais de sete anos. Aliás, parte da região do Projeto está incluída no chamado 'Polígono da Seca', mesmo havendo rios entrecortando os municípios em questão. São, porém, rios sazonais, que também secam nos períodos de seca. Antes da implementação do Projeto, os poços naturais e represas eram escassos e de difícil acesso para os produtores locais, razão pela qual grande parte dos trabalhos voltava-se justamente para a construção de represas e poços artesanais.

Devido a essas condições precárias, a região em questão não atraía grandes negócios agroindustriais. Ao contrário, em fins dos anos 1990, quando o projeto foi iniciado, predominavam ali as pequenas propriedades com menos de 100 hectares, exploradas pelos próprios proprietários, de sorte que cerca de $85 \%$ dos produtores da região eram donos da terra. Apesar do problema crônico da seca e da pobreza do solo de caatinga, cerca de dois terços da população ainda estava ligada a terra, os pequenos proprietários investindo na produção e transformação de produtos como a mandioca e o leite, fazendo uso prioritariamente da mão de obra familiar, sobretudo das mulheres.

Ao lado da atividade agrícola, apenas o pequeno comércio local e trabalho assalariado eventual serviam como fontes de renda, dando margem a altos índices de pobreza. De fato, de acordo com levantamentos realizados pelo órgão gestor do Projeto (SEPLANTEC/BA, s/d, documento interno), cerca de $65 \%$ das famílias tinham uma renda anual inferior a dois mil e quinhentos dólares, renda essa ainda mais escassa quando se leva em consideração que as taxas de natalidade eram altas - 5 a 6 filhos, em média -, não surpreendendo portanto as altas taxas de mortalidade infantil na região ( 88.2 por cada 1000 nascimentos). Ademais, menos de $35 \%$ das comunidades rurais da região dispunham de energia elétrica. Os postos de saúde eram raros e mal equipados e as escolas rurais muito poucas, pequenas e sem condições de ensino, só havendo escolas de segundo grau nas sedes dos municípios e, mesmo assim, oferecendo somente magistério e, mais raramente, curso técnico. Não por acaso, a região respondia pelas mais altas taxas de analfabetismo na Bahia, principalmente entre as mulheres: $53 \%$ da população feminina era analfabeta. Ademais, afastadas dos processos educacionais e excluídas dos sistemas de informação, essas mulheres não conseguiam ter acesso às conquistas sociais que já faziam parte do cotidiano de muitas mulheres brasileiras. Permaneciam, assim, totalmente alheias às condições mínimas de exercício da cidadania. 
Os únicos centros urbanos da região do Projeto eram as cidadezinhas sedes dos municípios: cidades pequenas, com poucos recursos e atrativos, não oferecendo oportunidades de trabalho suficientes para complementação da renda familiar. O que contribuía para que a migração, sobretudo para as cidades do Sudeste do país, São Paulo em especial, se colocasse como uma das principais estratégias de sobrevivência da população local.

Um levantamento realizado pela equipe de apoio constatou que todas as famílias visitadas tinham um ou mais membros trabalhando fora, a maioria em São Paulo. Em boa parte dos casos, eram as filhas que haviam migrado para trabalhar como empregadas domésticas, remetendo parte do salário para ajudar as mães. Na época da seca, porém, maridos e filhos homens já crescidos também partiam para o sul a procura de emprego, deixando as propriedades sob a responsabilidade das mulheres e crianças. Essa migração sazonal acontecia geralmente no início de abril, com o retorno dos maridos e filhos homens em novembro, época da preparação das roças para o plantio. Mas a seca podia se estender por longos períodos, obrigando os homens a permanecerem por anos seguidos no sudeste, uma situação que dava margem ao fenômeno sazonal das "viúvas da seca" e a uma alta proporção de unidades domésticofamiliares chefiadas por mulheres, o que em algumas comunidades rurais da área chegava a corresponder a mais de $80 \%$ das famílias (SEPLANTEC, Ba. s/d, documento interno).

Para parte desses migrantes, a ida para o sudeste podia se tornar algo permanente, já que as propriedades eram muito pequenas face ao tamanho das famílias: muita gente para herdar pouca terra. Não por acaso, um dos principais objetivos do Projeto era incentivar a permanência dos jovens na região, proporcionando incrementos na produção por meio da construção de represas e poços artesianos, capacitação em novas tecnologias e produtos alternativos, bem como a oferta de crédito rural para cooperativas locais.

Vale ressaltar que a fixação dos jovens e dos homens na região era um objetivo com o qual as mulheres também se identificavam, haja vista que a migração de membros da família para o sudeste sempre implicava no aumento da sua já pesada carga de trabalho. Como nos confidenciou uma das mulheres envolvidas: "Quando o homem da casa não está presente, as mulheres viram homens e mulheres da casa."

De um modo geral, as mulheres da região casavam ainda bastante jovens; mas, desde cedo, já eram responsáveis pelo cuidado de crianças, seus irmãos menores, bem como pelas tarefas domésticas 'ajudando' as mães. Mulheres de todas as idades tinham uma participação importante também na produção: as esposas deveriam 'ajudar' os maridos na roça, cuidar dos pequenos animais criados no quintal (porcos, galinhas), bem como preparar a farinha de mandioca e queijo para consumo da família e venda do excedente nas feiras locais. Tais atividades, ao lado da responsabilidade feminina pela a criação de animais de quintal e o plantio de hortas, eram desempenhadas como extensão dos trabalhos domésticos e, portanto, como de menor valor. 
Tal visão repercutia na definição dos índices de participação das mulheres na composição da força de trabalho na região. Dados estatísticos da década de 1980 apontavam que as mulheres respondiam por apenas $21.1 \%$ da população economicamente ativa. Na década de 1990, contudo, mudanças na metodologia usada pelo IBGE na coleta de dados passaram a visualizar melhor o trabalho feminino no campo, elevando o percentual de participação feminina para $46 \%$ da força de trabalho (SEPLANTEC/Ba, s/d, documento interno).

À bem da verdade, as relações de gênero na área não se diferenciavam muito do que se observa, ainda hoje, em grande parte do mundo rural. Predominavam as atitudes e valores tradicionais relativos à divisão sexual do trabalho e às tarefas destinadas às mulheres, dentro de uma ordem patriarcal de gênero. As mulheres na zona rural não só tinham menos acesso à educação, serviços de saúde e oportunidades de emprego assalariado do que aquelas vivendo em cidades de maior porte, como também se viam muito mais dependentes dos homens e da família, presas a um sistema de relações de gênero mais desiguais. E tal como acontece nas zonas rurais pelo mundo, também na região a ordem de gênero patriarcal, não só limitava seus direitos à titulação da terra, como também o controle sobre os produtos do seu trabalho e sua participação nas instâncias decisórias (WOORTMANN, 1995).

Sem dúvida, fazia-se necessário investir em um trabalho de sensibilização que desconsertasse mentalidades tradicionais, que transformasse as relações de gênero dominantes e que possibilitasse um processo contínuo de aprendizado político e participativo na construção de uma cidadania real para as mulheres. Tal convicção nos motivou a elaborar e desenvolver o PAGE na Região do Rio Gavião.

\section{O Projeto Gavião}

Implementado pela CAR, órgão da Secretaria de Planejamento do Estado da BahiaSeplantec, o Projeto Gavião baseava-se em duas vertentes - desenvolvimento técnicoeconômico e desenvolvimento comunitário -, não incluindo, originalmente, nada específico para mulheres. Para desenvolver o projeto, a área em questão fora dividida em quatro subregiões, cada uma com um escritório local, denominado de UAP (Unidade de Apoio ao Projeto) tendo um engenheiro agrônomo com coordenador, uma assistente social e cerca de 3 a 6 técnicos agrícolas como parte da equipe local, havendo apenas uma mulher técnica agrícola em todo o projeto. ${ }^{5}$ Cada técnico era responsável por um município dentro da região, trabalhando cada um com cerca de 8 a 10 comunidades. A maior parte desses técnicos era de nativos da

\footnotetext{
${ }^{5}$ A Coordenação Regional ficava no Município de Tremedal, onde ficava também a sede da UAP-Tremedal, responsável também pelos trabalhos em Anagé e Belo Campo; UAP-Presidente Jânio Quadros, coordenando Guajerú e Jacaraci; UAP-Mortugaba, coordenando Condeúba e Cordeiros; e UAP-Licínio de Almeida, coordenando Maetinga e Piripá.
} 
região, oriundos das Escolas Família Agrícola, onde jovens de ambos os sexos eram treinados para o trabalho na agricultura familiar, concedendo-lhes diploma de nível técnico. ${ }^{6}$

Para garantir um trabalho conjunto, havia uma Coordenação Regional, com dois engenheiros agrícolas e uma assistente social como monitores. Esses monitores visitavam as diferentes subunidades durante a semana, a assistente social sendo responsável pela coordenação regional do trabalho das assistentes sociais em cada escritório. A divisão sexual do trabalho, portanto, se mantinha em que o trabalho técnico agrícola era de responsabilidade masculina e o desenvolvimento comunitário, o trabalho social, da alçada feminina.

A direção do projeto ficava em Salvador, na Secretaria de Planejamento, tendo uma mulher como coordenadora geral. Duas outras mulheres participavam como coordenadoras de área, uma socióloga, responsável pelo desenvolvimento comunitário, e uma economista, responsável por avaliação e monitoramento. Um engenheiro agrícola coordenava o desenvolvimento produtivo, enquanto outro se responsabilizava pelas atividades relativas à construção de poços, represas e reservas. No escritório central havia ainda uma secretária e um técnico em contabilidade, obedecendo também aí os padrões tradicionais de divisão sexual do trabalho. Mas note-se que embora houvesse mulheres na coordenação do projeto, isso não implicava em equidade de gênero no poder decisório, já que o órgão maior responsável pelo projeto era dirigido por homens e os aspectos ditos 'técnicos' do projeto se sobrepunham ao desenvolvimento social e comunitário. Isso se refletia de cima a baixo, de sorte que as assistentes sociais, a regional, inclusive, eram muitas vezes excluídas das atividades ditas 'técnicas', sendo subalternas à coordenação local do engenheiro agrônomo. Ademais, as mulheres da equipe não tinham acesso direto a transporte, dependendo sempre da boa vontade dos técnicos para conduzi-las às comunidades.

Durante os primeiros 18 meses do projeto, o trabalho se voltou para o levantamento e identificação das diferentes comunidades rurais em cada um dos municípios envolvidos, mobilizando os produtores para elaborarem um 'plano operativo comunitário'. Mas os esforços maiores estavam na construção de 95 poços na área do Rio Gavião e o desenvolvimento de centros de treinamento agrícolas - os CATS - que ofereciam às comunidades a oportunidade de participar no desenvolvimento de tecnologias agrícolas alternativas e testemunharem seus efeitos. Vários 'dias de campo' foram organizados nesses CATS, ou mesmo nas propriedades dos produtores envolvidos, para o treinamento no uso dessas tecnologias e disseminação de informação sobre produtos alternativos. Por exemplo, um tipo de melancia que pode ser usada tanto como alimento quanto fonte de água para animais, e que se mostra resistente à seca por até

\footnotetext{
${ }^{6} \mathrm{Na}$ época da realização do Projeto, as EFAs, - Escolas Família Agrícolas seguiam uma metodologia de trabalho conhecida por "Alternância". Os/as alunos/as ficavam quinze dias na escola e quinze em casa, onde deveriam cumprir uma rotina de atividades monitorada pela escola. Entretanto, além das disciplinas específicas, tais como, Engenharia Rural, Zootecnia e Economia Doméstica, a grade curricular também contemplava as disciplinas básicas constantes do programa do segundo grau.
} 
dois anos. Outros tipos de alimento para animais, mais apropriados para as condições ecológicas existentes, também eram promovidos para treinamento, assim como para 'reservas estratégicas' para a estação das secas.

A produção de melancias em alguns CATS foi muito bem sucedida, oferecendo produtos para distribuição nas comunidades. Mas a participação das mulheres era pequena nessas atividades de campo. $\mathrm{Na}$ verdade, as próprias mulheres não reconheciam a importância do seu trabalho. Elas se identificavam primordialmente como esposas e mães, poucas vezes se admitindo como produtoras. Em consequência, antes da nossa participação no projeto, poucas mulheres participavam das cooperativas locais de produtores e das atividades do projeto voltadas para melhorias na produção. As que se faziam presentes nos dias de treinamento estavam lá para cozinhar. Depois que começamos nosso trabalho com as mulheres, essa participação cresceu significativamente, de sorte que em um dos últimos dias de treinamento de campo dos quais tivemos notícias, de um total de duzentos participantes, oitenta eram mulheres.

\section{O Programa de Assessoria em Gênero - PAGE}

A inserção da perspectiva de gênero veio como política imposta pelo FIDA, órgão financiador do projeto, seis meses depois que o projeto já havia sido iniciado. O FIDA seguia então as exigências da ONU de implantação do Plano de Ação de Beijing, que demandava a incorporação de um enfoque de equidade de gênero e empoderamento de mulheres em todos os projetos, repassando essa exigência para a direção da SEPLANTEC/BA.

Fomos convidadas para participar do projeto pela coordenadora do desenvolvimento comunitário, que nos procurou no NEIM solicitando nossa assessoria na elaboração de um “projeto para mulher”, para aumentar a participação feminina. No início, resistimos a aceitar esse desafio. Embora tivéssemos experiência com treinamento e sensibilização, achávamos perigoso trabalhar para o governo do Estado: era sabido que tais projetos serviam para a formação de currais eleitorais no interior da Bahia e não tínhamos a menos intenção em servir como 'massa de manobra'. Ademais, nossa perspectiva era a do empoderamento para a libertação, não só para mulheres, mas para os grupos subalternos, em geral, o que implicava uma pedagogia feminista de empoderamento semelhante às pedagogias freireanas (SARDENBERG, 2008b), ou seja, de conscientização da população, chocando-se, portanto, com a postura conservadora do governo da Bahia na época.

Participando de um evento no Ceará no qual se discutia a incorporação do enfoque de gênero em projetos governamentais, assisti uma apresentação de proposta de empoderamento de mulheres, na verdade, de 'emprendedorismo' para mulheres, que me preocupou. E mais preocupada fiquei ao saber que quem a apresentara era uma consultora 'por conta própria', sem nenhuma identificação com os movimentos feministas, que se baseava apenas em um 'kit' para 
o trabalho com gênero, adquirido pela internet. Naquele momento, tive a convicção de que, por nosso compromisso com as lutas das mulheres da Bahia, deveríamos aceitar a proposta de trabalho no Projeto Gavião.

Mas, sem dúvida, estávamos cientes de que nosso conhecimento da vida no mundo rural era quase somente 'acadêmico'. Tínhamos uma larga experiência na implementação de projetos de extensão comunitária trabalhando com grupos de mulheres, mas em áreas urbanas, principalmente nos bairros de camadas populares de Salvador. O que poderíamos oferecer para um projeto de desenvolvimento rural? Percebemos também que grande parte de nosso trabalho se voltaria para a sensibilização da equipe do projeto para o trabalho com enfoque de gênero, equipe essa composta, na sua maioria, por engenheiros agrônomos e técnicos agrícolas, quase todos de origem rural, da região do projeto. Nós não tínhamos experiência em treinar/sensibilizar homens para questões de gênero, fora de um contexto acadêmico. Como deveríamos proceder? Não nos iludimos: sabíamos que enfrentaríamos muitos desafios. Mas decidimos enfrenta-los, firmes na ideia de desenvolvermos um trabalho com perspectiva de equidade de gênero, de sorte a criar condições necessárias para a participação feminina em pé de igualdade com a masculina no projeto.

Embora concordássemos com essa assertiva de que a implementação de programas paralelos para mulheres - como um fim em si só - tende a reforçar ao invés de erradicar as divisões de gênero existentes, de sorte que as mulheres continuam a ser excluídas do processo de desenvolvimento, acreditávamos - e ainda acredito eu - que programas voltados especificamente para mulheres podem ser um meio fundamental para se construir mais equidade de gênero, como ações afirmativas para determinado fim. ${ }^{7}$

Elaboramos, assim, uma primeira análise de gênero do projeto, onde discutimos seus diferentes componentes e formas de organização e como deveríamos proceder para alcançar nossos objetivos (SARDENBERG; COSTA; PASSOS, 1998). Essa proposta se baseava na noção de que trabalhar pela equidade de gênero implicaria em duas linhas de ação. Uma voltada

\footnotetext{
${ }^{7}$ Nesse ponto, cabe fazer a distinção entre 'igualdade' e 'equidade de gênero' e como o conceito de empoderamento aí se encaixa: "A noção de igualdade de gênero se refere à igualdade de direitos, responsabilidades e oportunidades entre mulheres e homens e meninas e meninos. Note-se que o oposto de "igualdade" não é "diferença" e sim "desigualdade", portanto "igualdade" aqui não significa que homens e mulheres sejam iguais, mas que seus direitos, responsabilidades e oportunidades não devem ser diferenciados em função do sexo de cada um. Mas a igualdade de direitos estabelecida juridicamente não assegura um automático exercício desses direitos pelas mulheres. Como vimos anteriormente, as ideologias e hierarquias de gênero, a divisão sexual do trabalho, e as relações de gênero patriarcais dominantes nas sociedades contemporâneas criam condições "reais" de vida e trabalho, significativamente diferentes para mulheres e homens, de sorte que mulheres não desfrutam das mesmas oportunidades e direitos em pé de igualdade com homens. A noção de equidade de gênero reconhece que as diferenças entre os sexos são transformadas, na prática social, em desigualdades de gênero. Reconhece, assim, a necessidade de programas específicos e políticas compensatórias que possam criar as condições para uma efetiva igualdade de gênero, contribuindo, também, para o empoderamento das mulheres. O termo empoderamento, um neologismo criado a partir da tradução do inglês empowerment, diz respeito aos processos através dos quais as mulheres se fortalecem, conquistando maior autonomia e controle sobre suas próprias vidas. Esse fortalecimento vem de dentro, mas políticas e programas podem contribuir "facilitando" o seu desencadear, criando condições que contribuam para a sua maior conscientização, para o desenvolvimento da autoconfiança, diversidade de escolha e maior acesso e controle sobre recursos para as mulheres" (SARDENBERG, 2010, p.49-50).
} 
para as necessidades práticas das mulheres, ou seja, aquelas oriundas da divisão sexual do trabalho e das ideologias subjacentes, que criavam necessidades específicas para mulheres creches, por exemplo. E outra que tivesse por bem os interesses estratégicos das mulheres, isto é, aqueles pertinentes às relações de poder desiguais entre homens e mulheres, estabelecidas pelas estruturas de gênero patriarcais, que se queria erradicar (MOSER; MOSER, 2005; MOLYNEUX, 1985).

Baseadas nessa perspectiva de "mão dupla", formulamos então um programa de ação, o Programa e Assessoria em Gênero ou PAGE, com os seguintes objetivos: a) ampliar e aumentar a participação das mulheres em atividades relacionadas à assistência técnica e treinamento em novas tecnologias agrícolas, bem como de aproveitamento dos solos e recursos hídricos; b) garantir o acesso das mulheres aos recursos produtivos, tais como, sistemas de crédito, poços e sistemas de irrigação e posse legal da terra; e c) garantir a equidade de gênero nas associações comunitárias e instâncias decisórias locais.

Desde o início, porém, tivemos dificuldade em chegar a um acordo com a direção do projeto sobre o que um programa de gênero deveria incluir e se 'fazer gênero' seria diferente de 'fazer feminismo'. Inicialmente, a direção pensava o programa apenas como um componente à parte, de geração de renda para mulheres, por meio da criação de grupos produtivos. Para tanto, a diretora geral solicitou que organizássemos quinze desses grupos na área do projeto, pelo menos um por município, acreditando que bastaria um programa dessa ordem para que a participação das mulheres no projeto fosse garantida. Sua noção era a de empoderamento na perspectiva liberal, voltada apenas para o empoderamento econômico das mulheres como uma atividade paralela, no estilo dos projetos de 'mulheres e desenvolvimento' (MED), discutidos anteriormente. Para ela, trabalhar com 'gênero' era o mesmo trabalhar com mulheres, razão pela qual ela defendia a criação desses grupos, embora depois, por insistência do consultor do FIDA, viesse a concordar que seria importante envolver as mulheres nas demais atividades do projeto.

Por outro lado, o engenheiro agrônomo responsável pelo braço técnico - que havia participado de oficinas de treinamento com o FIDA, onde se discutira gênero como envolvendo homens e mulheres - era contra um programa paralelo só para mulheres, a exemplo da criação dos grupos produtivos. Ele também se orientava por uma perspectiva liberal no que se referia à inclusão de mulheres no projeto, mas defendia a postura de que bastaria trazer as mulheres para as diferentes atividades do projeto, que elas seriam incluídas, automaticamente. Sua noção era a de complementariedade de gênero, ou seja, de papéis sexuais diferentes, mas complementares, ignorando, portanto, as 'relações de gênero', ou seja, as relações de poder desiguais entre homens e mulheres próprias da ordem de gênero patriarcal em vigência. Tínhamos o apoio da coordenadora do programa de desenvolvimento comunitário, mas a hierarquia que se impunha entre os componentes ditos 'técnicos' e os 'sociais' a colocava em uma posição subordinada em relação aos outros dois coordenadores de área, engenheiros agrônomos. 
Tudo isso nos envolveu em embates com a direção do projeto. Mas permanecemos firmes na postura de que gênero não deveria ser um mero subcomponente do projeto, representado apenas pela criação de grupos produtivos. Argumentamos que não adiantaria levar as mulheres para as outras atividades do projeto sem um processo que facilitasse o seu empoderamento, de sorte a permitir que participassem em condições de igualdade com os homens. E, conseguimos, por fim, trabalhar com essa perspectiva de mão dupla, não agradando, porém, nem gregos nem troianos.

\section{Sensibilização e Capacitação da Equipe}

Por certo, os embates enfrentados tornaram evidente a necessidade de um trabalho contínuo de sensibilização e capacitação da equipe. Sabe-se que esse é um paço fundamental em qualquer esforço de transversalização de gênero; sem uma equipe engajada e que compartilha o desejo e compromisso de mudança nas relações de gênero, dificilmente se avança nessa direção. Mas o ideal é que a sensibilização para gênero aconteça antes da implementação dos projetos e, no caso do Projeto Gavião, tivemos que lidar não apenas com uma defasagem de mais de seis meses nesse processo, como também com uma estrutura patriarcal no órgão responsável e na divisão do trabalho e responsabilidades no projeto, os componentes ditos 'técnicos' se sobrepondo aos 'sociais' e 'comunitários'.

Vale lembrar que, das 32 pessoas que integravam a equipe técnica, havia apenas 7 mulheres, quase todas assistentes sociais (apenas uma técnica). Além disso, os homens detinham as principais posições de mando na coordenação regional e nas locais, todos eles engenheiros agrônomos, abertamente valorizando e, portanto, se dedicando mais aos componentes técnico-econômicos do projeto. Mesmo com a proposta de transversalizar gênero em todos os componentes e atividades, os agrônomos tendiam a ver o PAGE como parte do 'social' e, assim, dar menos atenção às atividades relacionadas.

Nos dois anos em que participamos do projeto, realizamos quatro seminários de sensibilização e capacitação para toda a equipe, elaborando cartilhas, manuais e outros materiais de treinamento para o trabalho com enfoque de gênero. Observamos, porém, que a diretora do projeto e os coordenadores homens só participaram do primeiro seminário, oferecendo sempre uma desculpa relativa ao trabalho para escaparem das demais, deixando evidente seu desinteresse pelo PAGE. Tal atitude prejudicou o processo de treinamento, pois não se trata de algo pontual, mas de um trabalho continuado (SARDENBERG, 2008b). Embora cada indivíduo caminhe no seu próprio ritmo, logo de início se estabeleceu uma defasagem entre a coordenação e a equipe de campo.

Conforme o previsto, realizamos oficinas mensais com a coordenação e equipes locais durante nossas visitas, não apenas para discutirmos mais a fundo os procedimentos 
metodológicos que seguíamos, mas também para avaliarmos o avanço da equipe no seu processo de conscientização e no trabalho com o enfoque de gênero. Esse procedimento era parte do processo de monitoramento do PAGE, buscando identificar as dificuldades surgidas em casa uma das sub-regiões e, em especial, as formas e níveis de resistência encontrados: a resistência não só por parte das comunidades das trabalhadas, mas, sobretudo, a dos próprios membros da equipe. Pudemos assim perceber que, quanto mais alto o status dos homens na hierarquia do projeto, maior sua tendência a resistir nossos esforços.

De fato, contrário às nossas expectativas, os técnicos se mostraram muito mais sensíveis na identificação dos padrões de relações de gênero na área rural, contribuindo significativamente para a formulação de um plano de ação mais específico à região. Conheciam bastante a região e as possibilidades de organização de grupos, identificando comunidades nas quais poderíamos trabalhar. Ademais, no nosso segundo seminário de sensibilização e capacitação das esquipes, eles nos surpreenderam participando ativamente das discussões, além de fecharem o evento com uma dramatização bastante sensível aos problemas enfrentados pelas mulheres na região.

Assim mesmo, nos meses de trabalho que se seguiram, a maior parte dos homens da equipe do projeto permaneceu resistente às ações que mexiam com as hierarquias e relações de gênero no espaço doméstico. Na verdade, todos os homens do projeto só apoiaram a introdução do enfoque de gênero por tratar-se de uma imposição do FIDA. Aliás, o próprio consultor do FIDA era um agrônomo, que não apoiava a ideia de empoderamento de mulheres; na reunião em que participou conosco e a coordenação do projeto, falou de gênero mas, o tempo todo, sua perspectiva era a do MED, ou seja, de incrementar a participação feminina no projeto, sem tocar na questão das relações de gênero.

\section{Seminários de Formação para Lideranças Femininas da Região}

Contribuir para o empoderamento de mulheres significa mexer com os padrões tradicionais de relações de gênero nessas comunidades e, portanto, envolve lidar com as diferentes formas de resistência que surgirão, e não apenas por parte dos homens envolvidos. Por certo, mulheres também têm medo de mudanças e resistem a tentativas de perturbar relações de gênero, mesmo quando isso possa trazer mudanças em seu benefício. Oficinas de sensibilização para gênero para mulheres da comunidade podem facilitar o deslanchar de um processo de conscientização, de sorte que elas venham, não apenas a entender o que isso implica, mas de fato demandar essas mudanças. Para tanto, é também necessário que se trabalhe no sentido de construir apoio dentre a comunidade local, articulando uma rede ampla, envolvendo tanto comunidades rurais, quanto as sedes dos municípios. 
Com tal perspectiva em vista, durante o primeiro ano da implementação do PAGE realizamos 13 seminários de um dia para lideranças femininas das sub-regiões, um por município, o que se traduziu em uma atividade envolvendo um total cerca de 700 mulheres da Região do Rio Gavião. Participaram lideranças das comunidades rurais, bem como das sedes dos municípios, incluindo-se, dentre elas, vereadoras, membros do secretariado das prefeituras, diretoras de escolas, delegadas e juízas locais, ou seja, mulheres em uma posição de construir apoio às atividades e objetivos do PAGE. $^{8}$ Isso possibilitou uma importante troca entre lideranças femininas da zona rural e da cidade, criando laços para a organização das mulheres da sub-região.

De um modo geral, os seminários foram realizados no espaço das Escolas Família Agrícola das sub-regiões, os internos e internas preparando as refeições a serem servidas durante o evento. Na parte da manhã, eram apresentados o Projeto Gavião e o PAGE, seguindose uma dinâmica de entrosamento das participantes. Após um intervalo para café, elas assistiam ao vídeo "Acordo Raimundo, Acorda", 9 mostrando as peripécias de um casal no qual a divisão sexual do trabalho e os papéis de gênero estão invertidos, abrindo-se, depois, uma roda de discussão sobre as questões levantadas no vídeo. Nessas discussões, as mulheres falavam da violência contra mulheres e reclamavam da invisibilidade do trabalho realizado por elas, mesmo quando trabalhando em atividades produtivas ao lado de seus companheiros, cuidando das roças, plantando ou cuidando dos animais. Elas lamentavam essa situação, afirmando que seu trabalho era quase sempre visto como mera 'ajuda'. Em um dos seminários, essa situação foi bem caracterizada em uma competição de versos sobre o trabalho da mulher entre times formados pelas participantes.

Dinâmicas e jogos semelhantes também eram utilizados nas sessões da tarde para abrir a discussão sobre a exclusão das mulheres da esfera pública, sua longa batalha para conquistar direitos constitucionais e o importante papel desempenhado por lideranças femininas nessas lutas. Em apoio às discussões, as mulheres participantes receberam cartilhas do Projeto e material específico para a formação de lideranças, elaborado pela equipe do PAGE.

A receptividade por parte das participantes foi sempre muito boa, com avaliações sempre positivas, a exemplo das falas registradas ao final do Seminário realizado em Licínio de Almeida, em 14 de junho de 1999:

"Prá gente que trabalha na roça foi muito importante para não estar depois reproduzindo as coisas como professoras e mães. Deu um clarão pra ver o que está errado".

"Além de ser um dia de troca, foi um dia que a gente parou pra ver a gente, foi nosso dia internacional da mulher. São coisas que estão na nossa vida e a gente viu que é da vida das outras também".

\footnotetext{
${ }^{8}$ O Projeto oferecia transporte e alimentação a todas as participantes.

${ }^{9} \mathrm{O}$ vídeo encontra-se disponível em: https://www.youtube.com/watch?v=HvQaqcYQyxU
} 
"Foi bom ouvir coisas novas e interessantes. Vou poder passar para outras pessoas. Não teve nada negativo".

"Excelente, acho que só se cresce com reuniões. Todo mundo que sair daqui vai ser diferente. Gostei do trabalho com os valores, que hoje estão muito abandonados".

"O tempo foi curto. Só assim as mulheres da roça podem aprender, podem vir sem os maridos".

\section{Seminários de Sensibilização para Professoras e Professores da Região}

Quando iniciamos nosso trabalho com o PAGE, a introdução de um enfoque de gênero em programas de desenvolvimento rural era então uma política bastante recente no Brasil, que enfrentava muitos obstáculos. Embora agências governamentais, técnicos extensionistas e as próprias comunidades rurais beneficiárias apoiassem e incentivassem projetos de geração de renda, ou que de outra forma atendessem às 'necessidades práticas' das mulheres (MOSER; MOSER, 2005), ações e atividades voltadas para seus interesses estratégicos, ou seja, que propiciassem seu empoderamento, não eram facilmente aceitas. Para tanto, era necessário trabalharmos em várias frentes ao mesmo tempo, buscando o apoio de pessoas chaves nas comunidades beneficiárias, que pudessem contribuir para uma opinião pública local favorável.

$\mathrm{Na}$ zona rural, onde os índices de analfabetismo ainda estão muito acima da média, professoras e professores são tidos em alta consideração, razão pela qual devem ser engajados nesse processo, inclusive por terem um papel crucial na formação das novas gerações. Sensibilizar professoras e professores das zonas rurais no tocante às questões de gênero se coloca assim, como uma importante estratégia para programas que visem a introdução de um enfoque de equidade de gênero.

Com tal propósito em mente, organizamos e conduzimos treze oficinas de um dia - uma para cada município do projeto - voltadas especialmente para professoras e professores. Nessa atividade, tivemos o apoio das secretarias de educação municipais e pudemos assim reunir um total de 800 professores e professoras de área do projeto nas 13 oficinas. Causou surpresa que, contrário ao que se observa na maior parte das cidades brasileiras onde menos de $5 \%$ de professores do ensino fundamental são homens, entre os participantes dos nossos seminários esses índices correspondiam a 35\%. No tocante à idade, esta variava dos 18 aos 55 anos, sendo que pouco mais de $60 \%$ estava na faixa dos 20 aos 30 anos.

Antes do início de cada Seminário, solicitamos aos participantes que preenchessem um questionário para conhecer seu nível de sensibilização para gênero. Em especial, as questões se voltavam para as relações de gênero na sala de aula, para tentarmos detectar se as desigualdades de gênero eram naturalizadas e se meninos e meninas recebiam tratamento diferenciado. Os resultados confirmaram a importância dos seminários para o professorado rural da região: mais de $85 \%$ dos respondentes demonstraram sustentar estereótipos de gênero e reforça-los nas salas de aula. Essa tendência era mais pronunciada entre os homens, particularmente aqueles acima dos 40 anos, uma tendência que também se revelou entre as mulheres: quanto mais velhas, 
maior sua tendência a naturalizar as desigualdades de gênero. Independente do sexo ou idade, contudo, participantes do seminário demonstraram grande interesse pelas questões discutidas e no material elaborado especificamente para eles.

A estrutura dos seminários para o professorado foi bastante semelhante a dos seminários para lideranças femininas, utilizando-se o mesmo vídeo ("Acorda Raimundo, Acorda”), mas para provocar uma discussão sobre masculino e feminino na escola. Discutiu-se, em especial, como o processo de socialização - no qual a escola tem um papel importante - molda crianças para se tornarem 'mulheres' e 'homens' de acordo com as ideologias dominantes. No período da tarde, nos concentramos em trabalhar a ideia de uma educação não discriminatória na escola, utilizando, para tanto, cantigas, técnicas de dramatização e o material específico elaborado para distribuição entre o professorado da região. Fechamos o seminário discutindo o papel das escolas em treinar meninas e meninos em técnicas produtivas, estressando a importância de mulheres e meninas participarem nas atividades do Projeto Gavião.

As avaliações dos participantes, bem como das secretarias municipais de educação dos municípios envolvidos, foi extremamente positiva. Fomos inclusive chamadas para realizar mais seminários, uma das secretarias até sugeriu que elaborássemos um programa especial de formação para o trabalho com gênero para o professorado da região.

\section{Criando Grupos Produtivos e de Conscientização e Ação}

Ainda que a ideia original para a criação dos grupos produtivos de mulheres não tenha sido nossa, vimos neles uma estratégia crucial como ação específica voltada para o empoderamento de mulheres. Assim, de acordo com essa posição, nos empenhamos na formação de grupos distribuídos pelos treze municípios da região do projeto.

A escolha desses grupos se deu a partir de um levantamento realizado pelas equipes locais, identificando as comunidades com maior potencial, já tendo algum trabalho iniciado nesse sentido ou laços preexistentes que propiciassem o trabalho em grupo. Visitamos essas comunidades e grupos sugeridos e, deliberando em colaboração com as equipes locais, escolhemos quinze grupos: um já operante voltado para a criação de cabras; dois nos quais as mulheres já desenvolviam atividades de geração de renda (bordados e cerâmicas), mas individualmente; dois em que já existia uma tradição de organização das mulheres, embora não voltada para geração de renda; e os outros dez caracterizados por redes sólidas de mulheres, seja por parentesco ou atividades religiosas, que demonstraram um potencial organizativo ou para a produção. Juntos esses grupos reuniram um total de aproximadamente 450 mulheres, ainda que variando bastante em termos do número de participantes (de 15 a 60 mulheres), bem como em termos de faixa etária, situação conjugal e grau de educação formal. 
Nossa primeira tarefa com os grupos foi facilitar a tomada de decisões sobre que atividades produtivas desenvolveriam, uma questão que levou em conta não apenas o potencial e desejo das participantes, como também as possibilidades regionais de comercialização dos produtos, além de uma avaliação do que seria necessário obter para levar o trabalho adiante. $\mathrm{O}$ plano original definia que os técnicos do projeto ofereceriam a capacitação necessária para a produção, enquanto nós trabalharíamos no sentido de reforçar os laços associativos das participantes dos grupos, bem como de facilitar a sensibilização para questões de gênero e direitos das mulheres por meio de oficinas. Baseando-nos nas metodologias das pedagogias feministas, herdadas dos grupos de conscientização e ação da Segunda Onda feminista (SARDENBERG, 2008b), realizamos nove oficinas mensais com cada grupo. Dentre os tópicos específicos, incluíram-se trabalho, saúde, direitos e violência contra mulheres, engajando-se, para tanto, a colaboração de especialistas e trabalhando sempre a partir das experiências e conhecimento prático das mulheres, no sentido de uma reflexão coletiva sobre relações de gênero e a situação das mulheres e os caminhos para transformá-las.

Um dos objetivos era elevar a autoestima das participantes, propiciando sua conscientização sobre a importância do seu trabalho na família. Para tanto, diferentes dinâmicas de grupo, tais como, jogos, dramatizações, desenhos e colagens, dentre outras atividades, foram utilizadas. Tendo em vista os altos níveis de analfabetismo, principalmente entre mulheres, na região, tivemos o cuidado de usar materiais e técnicas que não exigissem capacidade de leitura.

O trabalho que desenvolvemos com esses grupos permitiu a realização do levantamento de um amplo leque de informações sobre relações de gênero e situação das mulheres na área do projeto, bem como conhecer melhor as necessidades específicas das mulheres da região e suas expectativas sobre 'desenvolvimento', de sorte a formular ações que se adequassem a elas, inclusive a elaboração de cartilhas baseadas na própria experiência das mulheres. Contribuiu também para o fortalecimento das organizações e redes de mulheres existentes, oferecendo ainda incentivos para a criação de novos grupos, bem como apoio às atividades de geração de renda já existentes, por meio de treinamento e acesso a linhas de crédito. Em especial, o treinamento das mulheres participantes em técnicas produtivas propiciou sua capacitação para atuarem como multiplicadoras dessas novas tecnologias e de novas atitudes e valores. Além disso, propiciou o treinamento de campo para técnicos e técnicas do projeto no tocante à sensibilização para gênero, dinâmicas de grupo e novas metodologias, para que promovessem também a inserção da perspectiva de gênero nas ações do projeto. No final da série de oficinas, solicitamos que as participantes fizessem uma avaliação dos trabalhos, da maneira que achassem melhor. A maior parte dos grupos escolheu fazer dramatizações que enfatizaram seus sentimentos de crescimento pessoal, de aumento da autoestima e da solidariedade entre os membros do grupo. 
Embora as dinâmicas utilizadas no trabalho com os grupos envolvessem geralmente jogos, brincadeiras ou dramatizações que propiciaram um clima bem-humorado para os trabalhos, alguns momentos foram bastante emotivos, principalmente quando questões relativas à violência doméstica vieram à baila. Ressalte-se que essa questão - a da violência doméstica contra mulheres - foi foco de conflitos entre alguns dos coordenadores locais e a nossa equipe. Eles insistiram que trabalhar tal questão fugia dos propósitos do projeto mais amplo, e que discuti-la com as participantes poderia resultar na perda do apoio dos homens para o projeto. Um dos coordenadores locais chegou a levar a questão para a Direção do projeto, que concordou com ele. Ficou evidente, então, que também para a Direção, trabalhar com gênero deve se limitar a promover a participação de mulheres em atividades produtivas e propiciar o aumento de sua autoestima, sem, contudo, tocar no que se referia aos padrões de relações de gênero na região, sobretudo no que se referia à violência doméstica. Facilitar o empoderamento de mulheres no sentido de combater esse tipo de violência era, pois, tido como 'fazer feminismo' e não 'trabalhar com gênero' e, portanto, deveria ser evitado, mesmo quando as próprias mulheres envolvidas haviam identificado a violência doméstica com um dos principais problemas que as atingia.

Os coordenadores locais também se mostraram resistentes à formação e desenvolvimento dos grupos de mulheres, deixando de oferecer-lhes o apoio necessário. Eles identificavam esses grupos como sendo os "grupos do NEIM", vendo-os como parte do componente de desenvolvimento comunitário e, assim, como 'menos importantes' do que as outras atividades sob sua responsabilidade. Argumentando que sua equipe técnica estava com 'excesso de trabalho' (o que não deixava de ser verdade), eles priorizavam as ações do componente dito 'técnico', demorando em oferecer a matéria prima e o treinamento necessário para as atividades produtivas dos grupos de mulheres deslancharem.

Quando questionamos essa atitude durante uma reunião mensal com a equipe de uma das UAPs, o coordenador, por assim dizer, 'perdeu a linha', vociferando impropérios contra nosso trabalho. Trouxe à baila, inclusive, uma instância de discussão sobre a questão da violência contra mulheres ocorrida em uma comunidade local, falando da reação contrária dos homens. Reclamou que havíamos sido contratadas para 'fazer gênero' e não 'feminismo' no projeto e que nossas 'cabeças iriam rolar...'

E, de fato, em se tratando de um dos coordenadores locais mais chegados à Coordenação Técnica do Projeto, não tardou muito fomos chamadas por um dos diretores da CAR que nos falou, de forma sinuosa mais perfeitamente perceptível, que nossos serviços já não eram mais necessários. Por nos defender, a coordenadora do componente comunitário do Projeto também acabou sendo afastada. Mas nosso Programa de Assessoria em Gênero não foi totalmente descartado. Continuou a ser desenvolvido, mas sem o teor feminista de empoderamento das mulheres. 


\section{Considerações Finais}

Em trabalho anterior (SARDENBERG, 2010), observei que por procurar romper com os padrões estabelecidos das relações de poder entre os sexos, a perspectiva de Gênero e Desenvolvimento se tornou um grande desafio, encontrando toda sorte de resistência. Ademais, vez que a incorporação dessa perspectiva se tornou praticamente obrigatória em projetos e programas financiados por agências de cooperação internacional, como no caso do Projeto do Rio Gavião na Bahia, operou-se uma tradução mais de acordo com a política dos órgãos locais responsáveis, resultando em versões ditas 'descafeinadas' de equidade de gênero e empoderamento de mulheres.

Por certo, os projetos de Mulher e Desenvolvimento, voltados fundamentalmente para o atendimento das necessidades práticas de gênero das mulheres, ou seja, das necessidades relativas às responsabilidades femininas, eram mais palatáveis. Conforme destaquei no referido trabalho (SARDENBERG, 2010, p.65), “[...] nos contextos do planejamento e execução de projetos é muito mais fácil identificar e atender a essas necessidades - como, por exemplo, criar creches, oferecer suprimento de água limpa nas proximidades da casa, oferecer cursos de costura, de restaurante, para lavadeiras etc., - bem como a sua legitimidade. Incluem-se aí também intervenções no sentido de organizar as mulheres e promover a sua autoestima."

Ora, reconhecer a legitimidade dessas demandas e procurar atendê-las não implica sempre em mudança de mentalidades, tampouco traz ameaças às estruturas de poder e padrões de comportamento existentes, a começar pelo que se refere à estrutura organizacional dos órgãos e agências envolvidas nas ações do projeto. Em contrapartida, na forma em que foi originalmente concebida, a abordagem de Gênero e Desenvolvimento significaria não apenas o atendimento das necessidades práticas das mulheres, mas sobretudo dos seus interesses estratégicos de empoderamento, o que poderia implicar em: "[...] acesso igual ao poder de decisão, redução ou finalização da discriminação institucionalizada no trabalho, direito à propriedade da terra e à educação, medidas para erradicar a violência masculina contra as mulheres e a divisão da responsabilidade com homens nos cuidados com as crianças" (WILLIAMS, 1999, p.15). Atendê-las, portanto, implicaria em questionar ou mesmo botar por terra os privilégios masculinos existentes. E implicaria, ainda, em uma mudança nos critérios de prioridades de projetos, questionando a divisão entre os componentes ditos 'técnicos' e 'sociais', impondo-se, outrossim, como uma problemática transversal e, portanto, abrangente. O que, sem sombra de dúvida, exige muito mais tempo, compromisso e dedicação do que as abordagens anteriores.

De fato, conforme nos aponta Williams (1999, p.13), é preciso ter em mente que o enfoque de equidade de gênero '[...] não pode ser simplesmente 'costurado' aos modelos de 
desenvolvimento existentes, nem tampouco adicionado aos programas de ajuda e desenvolvimento como um componente extra." Trata-se de um enfoque que deve atravessar todos os componentes dos programas e projetos, demandando maior articulação entre as ações ditas técnicas e sociais desses programas.

Nossa experiência nesse projeto nos alertou também para a necessidade de uma sensibilização e formação constante das equipes e coordenações envolvidas, de cima a baixo, em questões de equidade de gênero e empoderamento de mulheres. Isso porque se trata de uma “[...] intervenção de desenvolvimento que busca modificar consciências, conhecimento, habilidades e comportamentos relacionados a gênero. Ela difere de formações com outros conteúdos/temas, porque trata de questões pessoais e políticas, mesmo que não seja de modo deliberado" (WILLIAMS, 1999, p.21). Daí porque se verifica uma diferença relevante entre a formação em gênero e a formação (ou capacitação) em outros conteúdos e temáticas relacionados à implementação de projetos de desenvolvimento. Em especial, o objetivo maior da sensibilização e formação para intervenções com enfoque de gênero vai além de apenas habilitar os agentes envolvidos para trabalhar com a questão; o que se pretende é contribuir para a formação da sua autoconsciência crítica de gênero.

Nesse sentido, podemos dizer que nosso trabalho produziu resultados positivos. Tempos depois de nosso afastamento do projeto, encontramos gente da coordenação e equipe do projeto estudando gênero em cursos de pós-graduação e mulheres que participaram dos seminários e grupos produtivos que organizamos participando como delegadas em conferências municipais e estaduais de políticas para mulheres na Bahia, ou até mesmo atuando como vereadoras e secretárias municipais, na defesa de questões de promoção social das mulheres. Esses encontros têm contribuído para transformar as memórias de experiências doídas em satisfação com os frutos, ainda que tardios, do nosso trabalho.

\section{Referências}

ALSOP, R.; BERTELSEN, M.F.; HOLLAND, J. Empowerment in Practice: From Analysis to Implementation, Washington DC: The World Bank, 2006.

ALVAREZ, S. "Construindo uma política feminista translocal da tradução". Revista Estudos Feministas, Florianópolis, 17(3), 2009: p. 743-753.

BADEN, S.; GOETZ, A. M. 'Who needs [Sex] when you can have [Gender]? Conflicting Discourses on Gender at Beijing', Feminist Review, N.56, 1997: p. 3-25.

BATLIWALA, S. 'The Meaning of Women's Empowerment: New Concepts from Action', in G. Sen, A. Germain and L.C. Chen (eds), Population Policies Reconsidered: Health, Empowerment and Rights, Boston: Harvard University Press, 1994. 
BEDLINGTON, N. Transforming the mainstream: seminar report on mainstreaming and inclusive approaches in EU development cooperation. Aprodev, HelpAge International, Wide, One World Action, 2004.

CONNELLY, M.P., MACDONALD, M.; PARPART, J.L. 'Feminism and Development', in J.L. Parpart, M.P. Connelly and V.E. Barriteau (eds), Theoretical Perspectives on Gender and Development, Ottawa: IDRC, 2000.

COSTA, C. L. "As teorias feministas nas Américas e a política transnacional da tradução', Revista Estudos Feministas, Vol. 8, no. 2, 2000: p. 43-48.

FERGUSON, A. 'Can Development Create Empowerment and Women's Liberation?', paper presented at the 2004 Center for Global Justice Workshop 'Alternatives to Globalization'. Disponível em: http://www.globaljusticecenter.org/papers/ferguson.htm. Acessado em 20/08/2008.

FERREIRA, V. "A globalização das políticas de igualdade entre os sexos: do reformismo social ao reformismo estatal." In: GODINHO, Tatau; SILVEIRA, Maria Lúcia (Orgs.). Políticas públicas e igualdade de gênero. São Paulo: Prefeitura Municipal de São Paulo. Coordenadoria da Mulher, 2003: p. 77-102.

KABEER, N. Reversed Realities. Gender Hierarchies in Development Thought. London: Verso, 1994.

MOSER, C.; MOSER, A. Gender mainstreaming since Beijing: a review of success and limitations in international institutions. In: PORTER, Fernella; SWEETMAN, Caroline (Eds.). Mainstreaming gender in development: a critical review. Oxford: Oxfam GB, p. 11-23, 2005.

MOLYNEUX, M. "Mobilization without emancipation? Women's interests, the state, and revolution in Nicaragua." Feminist Studies, vol. 11, No.2, p.227-254, 1985

PISCITELLI, A. "As viagens das teorias no embate entre práticas acadêmicas, feminismos globais e ativismos locais". Gênero nas fronteiras do sul, 2005: pp.143-163.

RAZAVI, S. and MILLER, C. From WID to GAD: Conceptual Shifts in the Women and Development Discourse, Geneva: UNRISD, 1995.

ROGERS, B. The Domestication of Women. Discrimination in Developing Societies. London: Tavistock, 1981.

ROMANO, J.O. 'Empoderamento: Recuperando a Questão do Poder no Combate à Pobreza', in J. Romano and M. Antunes, Empoderamento e Direitos no Combate à Pobreza, Rio de Janeiro: ActionAid, 2002.

SARDENBERG, C. "Migrações Perigosas: As (Des)Aventuras Semânticas do Conceito de Gênero nos Projetos e Políticas para Mulheres no Brasil". In: E. GONÇALVES et ali (orgs.), Iguais? Gênero, Trabalho e Lutas Sociais. Goiânia : Editora da PUC Goiás, p. 19-48, 2014: p. 19-48.

SARDENBERG, C. "Da Transversalidade à Transversalização de Gênero". In: I.ALVES; M.L. SCHEFLER; P. VAZQUEZ; AQUINO, S. (orgs), Travessias de Gênero na Perspectiva Feminista. Salvador : NEIM/EDUFBA, 2010: p. 37-73. 
SARDENBERG, C. "Liberal vs Liberating Empowerment: A Latin American Feminist Perspective on Conceptualising Women's Empowerment." IDS Bulletin, Vol.39, N.6, 2008a: p.18-27.

SARDENBERG, C. "Considerações introdutórias às pedagogias feministas." In: A.Costa, A.Rodrigues, I.Vanin (orgs.), Ensino e gênero: perspectivas transversais. Salvador: NEIM/UFBA, 2008b: p.15-30.

SARDENBERG, C. "Introducing Gender Awareness to Elementary School Teachers in Bahia, Brazil." In: IV International Conference Of The Centre For Women In Rural Development: Knowledge, Education And Extension For Women In Rural Areas, Wissen, Bildung und Beratung für Frauen im ländlichen Raum. Berlin, Alemanha: Universitätsdrucherei der HUB/tuposatz GmbH Berlin, 2000. p. 46-54.

SARDENBERG, C.; PASSOS, E.; COSTA, A. "Rural Development in Brazil: Are we Practising Feminism or Gender?" Gender and Development, Vol. 7, Number 3, 1998: p. 28-38.

SEN, G.; GROWN, C. Development, Crisis, and Alternative Visions: Third World Women's Perspectives, London: Development Alternatives with Women for a New Era, 1988.

SIMIÃO, D. 'As coisas fora do lugar. Gênero e o potencial de programas de geração de emprego e renda', in C. Buarque (ed.), Perspectivas de Gênero: Debates e Questões para as ONGS. Recife: GT Gênero - Plataforma de Contrapartes NOVIB/SOS Corpo, Gênero e Cidadania, 2002: p. 80-93.

STROMQUIST, N. 'Education as a Means for Empowering Women', in J. Parpart, S. Rai and K. Staudt (eds), Rethinking Empowerment: Gender and Development in a Global/Local World, London: Routledge, 2002: p. 15-28.

UNITED NATIONS. World Survey on the Role of Women in Development. New York: United Nations, 1989.

UNITED NATIONS. Plan of Action. IV World Conference on Women. New York: United Nations, 1985.

VERLOO, M. Gender mainstreaming: practice and prospects. Netherlands: Univ. of Nijmegen, 1999.

WILLIAMS, S. (org.). Manual de formação em gênero. Recife: OXFAM/ SOS Corpo, Gênero e Cidadania, 1999.

WILSON, K. 'Feminism and Development: Efficiency, Choice or Liberation?', 2004. http://www2.hud.ac.uk/hhs/cdg/research/conferences/0411/papers/develop.php

WOORTMANN, Ellen. Herdeiros, Parentes e Compadres. Brasília, D.F.: Editora Universidade de Brasília, 1995.

YOUNG, K.; WOLKOWITZ, C.; McCULlAGH, R., (eds). Of Marriage and the Market. Women's subordination internationally and its lessons. London: Routledge \& Kegan Paul, 1984. 
ZABALA, I. 'El Banco Mundial y su Influencia en las Mujeres y en las Relaciones de Género', Cuadernos de Trabajo de Hegoa No 41, October, Facultad de Ciencias Economicas (UPV/EHU), Bilbao: 2006. 